\title{
Political Institutions and Economic Policies: Lessons from Africa
}

\section{Citation}

Humphreys, Macartan, and Robert Bates. 2005. Political institutions and economic policies: Lessons from Africa. British Journal of Political Science 35, no. 3: 403-428.

\section{Published Version}

http://dx.doi.org/10.1017/S0007123405000232

\section{Permanent link}

http://nrs.harvard.edu/urn-3:HUL.InstRepos:3707094

\section{Terms of Use}

This article was downloaded from Harvard University's DASH repository, and is made available under the terms and conditions applicable to Other Posted Material, as set forth at http:// nrs.harvard.edu/urn-3:HUL.InstRepos:dash.current.terms-of-use\#LAA

\section{Share Your Story}

The Harvard community has made this article openly available.

Please share how this access benefits you. Submit a story.

Accessibility 


\title{
Political Institutions and Economic Policies: Lessons from Africa
}

\author{
MACARTAN HUMPHREYS AND ROBERT BATES*
}

\begin{abstract}
Many assert that the economic problems of Africa possess political origins. In particular, they point to a lack of political accountability and argue that economic reform and the renewal of growth depend upon political reform and in particular upon the promotion of competitive electoral politics. Summarizing these arguments, this article formalizes and tests them, using both an African and global sample of data. While it finds support for the view that within Africa - and globally - competitive institutions are associated with less extractive policies, it finds no evidence that these institutions have facilitated the implementation of Washington consensus policies.
\end{abstract}

Writing half a decade ago, Easterly and Levine spoke of Africa's 'Growth Tragedy'. What Easterly and Levine described in 1997 remains true today: Africa poses the development challenge of our time.

In periods of rapid development - such as the 1960s - growth rates in Africa lagged behind those in other regions; in periods of slow growth - such as the 1980s - growth rates in Africa turned negative. In recent decades, large parts of the continent have become poorer, both relative to other regions and in absolute terms. While incomes in Africa were approximately equivalent to those in Asia in 1950, incomes in Africa had fallen to approximately one quarter those of the latter region by the early 1990s. ${ }^{2}$ Table 1 shows the growth rates of the economies of the world, divided by region and era. Africa's growth tragedy, it can be seen, has been deep and sustained.

In this article we explore political determinants of Africa's economic performance. In particular, we focus on the policies of its governments and on the institutions that influence their policy choices. In Part I, we review the literature, focusing on arguments that emphasize the economic importance of public policies. In Part II, we explore the logic of political accountability, thus linking political institutions to policy choices; the analysis impinges directly on the debates linking economic development to political reform. In Part

\footnotetext{
* Department of Political Science, Columbia University; and Department of Government, University of Harvard, respectively. This article was originally presented at the Annual Meeting of the American Political Science Association, San Francisco, 2001. The authors would like to thank James Habyarimana, Karen Ferree, Smita Singh, Richard Tucker, John Gerring and Irene Yackovlev for their help and advice. Special thanks go to Philip Keefer for insightful comments given at the APSA meetings. This article was begun while Robert Bates was a visiting scholar with the World Bank and has been written with the support of the National Science Foundation (Grant SES 9905568) and the Carnegie Corporation. The authors also wish to acknowledge the support of the Center for International Development, the Weatherhead Center for International Affairs, the Harvard Academy for International and Area Studies, and the Africa Initiative of Harvard University. The authors alone are responsible for its contents, however.

1 W. Easterly and R. Levine, 'Africa's Growth Tragedy: Policies and Ethnic Divisions', Quarterly Journal of Economics, 112 (1997), 1203-50.

2 A. Maddison, Monitoring the World Economy 1820-1992 (Paris: OECD, 2000). Data from Tables 1-3. Note that Maddison reports the arithmetic mean of per capita income across a sample of countries (10 for Africa, 11 for Asia).
} 
III, we test our arguments. In doing so, we relate data on the institutional features of governments to their choice of policies, drawing on both African and global samples.

\section{PART I: PERSPECTIVES}

Many reasons have been offered for Africa's poor growth performance. Some, such as Sachs and Warner, focus on Africa's natural endowment: its tropical location, its resources, and its position in global markets. ${ }^{3}$ Others, such as Easterly and Levine, point to Africa's cultural endowment, and in particular to the number and fractionalization of ethnic groupings. ${ }^{4}$ Still others point to political factors and emphasize the quality of governance in Africa. This essay focuses on this last interpretation.

In doing so, it focuses on three literatures: one arising from qualitative accounts by political scientists and African intellectuals; a second from the efforts of economists to estimate cross-national growth equations; and a third from the international financial community.

\section{Qualitative Accounts}

In the immediate post-independence period, scholars, such as Walter Rodney ${ }^{5}$ and political leaders, such as Kwame Nkrumah, ${ }^{6}$ emphasized the political determinants of the economic performance of Africa. They pointed to the impact of external forces, such as colonial rule and the dependent position of Africa in the world order. Noting the growing disparity between the economic performance of the African nations and that of nations in regions with similar legacies and positions in the global economy, later scholars focused on internal determinants of economic behaviour in Africa. ${ }^{7}$ Some, such as Rene Dumont and Robert Bates have stressed the tendency of governments to adopt policies that sacrificed the public interest for private advantage. ${ }^{8}$ Still others, like Claude Ake, cite the lack of political accountability on the part of Africa's governments. ${ }^{9}$

Case studies lend support to the last set of arguments. In both Nigeria and Ghana, for example, military governments, being immune to electoral challenge, engaged in the wholesale looting of the national treasury. In Nigeria, the government of General Abacha diverted over $\$ 2$ billion of Nigeria's export earnings from the oil industry to private bank accounts abroad. In Ghana, the government of General Acheampong generated massive budgetary deficits and accommodated them so laxly that it debased the national currency, sending Ghana in a downward growth spiral from which it has taken decades to recover. ${ }^{10}$

3 J. Sachs and A. Warner, 'Sources of Slow Growth in African Economies', Journal of African Economies, 6 (1997), 335-76.

4 Easterly and Levine, 'Africa's Growth Tragedy'.

5 W. Rodney, How Europe Underdeveloped Africa (London: Bogle-L'Overture, 1972).

${ }^{6}$ K. Nkrumah, Neo-Colonialism: The Last Stage of Imperialism (New York: International Publishers, 1965).

7 M. Lofchie, 'The New Political Economy of Africa', in David E. Apter and Carl G. Rosberg, eds, Political Development and the New Realism in Sub-Saharan Africa (Charlottesville: University Press of Virginia, 1994), pp. $145-83$.

${ }^{8}$ R. Dumont, False Start in Africa (New York: Praeger, 1969); R. H. Bates, Markets and States in Tropical Africa (Berkeley and Los Angeles: University of California Press, 1981).

9 C. Ake, Democracy and Development in Africa (Washington, D.C.: The Brookings Institution, 1996).

${ }^{10}$ C. Leith and M. Lofchie, 'The Case of Ghana', in R. H. Bates and A. O. Krueger, eds, Economic and Political Interactions in Economic Policy Reform (Oxford: Blackwell, 1991), pp. 225-93. 
Abacha and Achaempong were officers who presided over military governments. Others, such as Kwame Nkrumah in Ghana and Kenneth Kaunda in Zambia, were civilians. But because they presided over single-party systems, they too were sheltered from electoral accountability. In Ghana, the government of Nkrumah seized the earnings of export agriculture to finance dozens of import substituting firms. The firms remained privately profitable because they were protected. The result was an inefficient transfer of resources from consumers to the political elites that dominated their boards and management. ${ }^{11}$ In Zambia, the government of Kenneth Kaunda maintained an overvalued exchange rate that transferred the hard currency earned from copper exports to state-owned enterprises. ${ }^{12}$ In both countries, government policies imposed a tax on exports; but because of the single-party system, the exporters could not organize in opposition to the government policies. The result in both cases was a rise in trade deficits and international debt.

Observing these and other cases, scholars - most recently van de Walle ${ }^{13}$ - have focused on the domestic origins of Africa's development crisis. They stress the inability, or unwillingness, of states to implement policies that provide benefits to the broader public rather than to the governments themselves, even in the face of the pressures orchestrated by the international financial community. Activists and intellectuals have also pointed out the political origins of economic decline in Africa. ${ }^{14}$ For Africa to recover economically, they argue, dictatorships and single-party regimes must give way to multi-party systems, with freedom to organize and to challenge incumbent governments. ${ }^{15}$ The road to economic recovery, they contend, lies in political reform, and especially in efforts to render governments politically accountable. ${ }^{16}$

\section{Quantitative Accounts}

In an effort to explain cross-national variation in rates of economic growth, economists have fitted a variety of econometric models to aggregate economic data. ${ }^{17} \mathrm{Be}$ these equations based on neoclassical or endogenous growth theory, researchers have often found it necessary to enter an 'Africa dummy'. The dummy is included to account for all things particular to Africa that are not accounted for by other explanatory variables. The sign on the dummy is negative and its coefficient significant, thus implying that, all else being equal, the economies of Africa achieve lower rates of economic growth than do those in other regions. In 1991, Barro found that even controlling for the level of public consumption and a measure of the distortion of markets, the dummy for Africa

11 T. Killick, Development Economics in Action: A Study of Economic Policies in Ghana (London: Heinemann, 1978).

12 R. H. Bates and P. Collier, 'The Case of Zambia', in Bates and Krueger, eds, Economic and Political Interactions in Economic Policy Reform (Oxford: Blackwell, 1991), pp. 382-443.

${ }^{13}$ See N. van de Walle, African Economies and the Politics of Permanent Crisis, 1979-1999 (Princeton, N.J.: Princeton University Press, 2001); also R. Bates, Essays on the Political Economy of Rural Africa (Berkeley and Los Angeles: University of California Press, 1987).

${ }^{14}$ See C. Achebe, Anthills of the Savannah (London: Heineman, 1987); also Ake, Democracy and Development in Africa.

${ }^{15}$ C. Ake, The Case for Democracy: African Governance in the 1990s (Atlanta, Ga.: Carter Center, 1990).

16 J. A. Wiseman, ed., Democracy and Political Change (London: Routledge, 1995); and R. Joseph, 'Africa: Rebirth of Freedom', Journal of Democracy, 2 (1991), 11-24; and World Bank, Governance and Development (Washington, D.C.: The World Bank, 1991); and G. Hyden and M. Bratton, Governance and Politics in Africa (Boulder, Colo.: Lynne Rienner, 1992).

17 R. Barro and X. Sala-i-Martin, Economic Growth (New York: McGraw-Hill, 1995). 
remained negative and significant. ${ }^{18}$ Controlling for measures of trade openness and fiscal restraint, Barro and Lee replicate this result. ${ }^{19}$ And even while adding financial depth to measures of trade openness and fiscal restraint, Easterly and Levine find a significantly lower rate of growth among African nations. ${ }^{20}$

The evidence of an 'African' effect also comes from the subjective ratings of the world's economies made by international investors. Investors appear to base their judgements on such economic fundamentals as the level of foreign reserves, fiscal balance and debt. But, as reported by Collier and Pattillo, even allowing for such factors, they place an additional discount on Africa's economies. ${ }^{21}$ A significant and negative 'Africa dummy' consistently enters equations that attempt to account for the scores conferred upon nations by those who rate their attractiveness for foreign investors. ${ }^{22}$

Some scholars account for this effect by considering geographic features associated with Africa. ${ }^{23}$ But many turn to explanations that are more political. Englebert stresses the legitimacy of state structures ${ }^{24}$ Easterly and Levine emphasize Africa's ethnic diversity. ${ }^{25}$ Collier stresses the importance of forms of government: ethnic make-up, he argues, affects rates of growth, but only in nations that lack democracy. ${ }^{26}$ The unexpectedly low rates of growth of the nations of Africa, he argues, may therefore derive fundamentally not from their ethnic diversity, but rather from their lack of democratic institutions. ${ }^{27}$

In a thoughtful review of this literature, Ndulu and O'Connell decompose the sources of growth between the accumulation of factors and the growth of total productivity. ${ }^{28}$ They attribute a portion of the lag in African growth rates over the period 1960-94 to high levels of fertility, and therefore to a low ratio of labour force to population; ${ }^{29}$ another portion they attribute to the slow accumulation of physical and human capital. But fully two-thirds of Africa's shortfall remains unexplained, they report, and they suggest that the unexplained portion may result from political factors, and in particular, from authoritarian rule. ${ }^{30} \mathrm{In}$ a

18 R. Barro, 'Economic Growth in a Cross Section of Countries', Quarterly Journal of Economics, 106 (1991), $407-43$.

19 R. Barro and J-W. Lee, 'Sources of Economic Growth', Carnegie-Rochester Conference Series on Public Policy 40 (University of Rochester, 1994), pp. 1-46.

20 Easterly and Levine, 'Africa's Growth Tragedy'. See also P. Collier and J. W. Gunning, 'Explaining Africa's Economic Performance', Journal of Economic Literature, 37 (1999), 64-111. An important study that does not identify an Africa specific effect is A. Hoeffler, 'Econometric Studies of Growth, Convergence and Conflicts' (doctoral dissertation, Oxford University, 1999).

${ }^{21}$ See N. U. Haque, M. Nelson and D. J. Mathieson, 'Risk in Africa: Its Causes and Its Effects on Investment', in P. Collier and C. Pattillo, eds, Investment and Risk in Africa (Basingstoke, Hants.: Macmillan, 1999), pp. 33-70.

${ }^{22}$ Collier and Pattillo, Investment and Risk in Africa.

23 Sachs and Warner, 'Sources of Slow Growth in African Economies'.

${ }^{24}$ P. Englebert, State Legitimacy and Development in Africa (Boulder, Colo.: Lynne Rienner, 2000).

25 Easterly and Levine, 'Africa's Growth Tragedy'.

26 P. Collier, Ethnicity, Politics, and Economic Performance (Washington, D.C.: The World Bank, 1999).

27 Barro also explored the impact of levels of democracy (see R. Barro, 'Democracy and Growth', Journal of Economic Growth, 1 (1996), 1-27). Changes in his measure (derived from R. Gastil, Freedom in the World (Westport, Conn.: Greenwood Press, 1982)) significantly relate to changes in growth rates, with the middle level of democracy associated with the most favourable rates of growth (Barro, 'Democracy and Growth', p. 14). Even controlling for the level of democracy of their governments, however, Barro finds that the African cases exhibited a significantly lower average rate of growth.

${ }^{28}$ B. Ndulu and S. A. O'Connell, 'Governance and Growth in Sub-Saharan Africa', Journal of Economic Perspectives, 13 (1999), 41-66.

${ }^{29}$ See also D. Bloom and J. Sachs, 'Geography, Demography, and Economic Growth in Africa', Brookings Papers in Economic Activity, 2 (1998), 207-95.

${ }^{30}$ Ndulu and O'Connell, 'Governance and Growth in Sub-Saharan Africa', p. 45. 
global study, Acemoglu, Johnson and Robinson use settler mortality rates as an instrument for contemporary institutions and find a positive relationship between political institutions and economic growth. Africa's slow growth results, they imply, from its politics. ${ }^{31}$

\section{International Financial Institutions}

As recounted in its official history, as the World Bank expanded its role in Africa, its in-house project evaluations revealed a distressingly low rate of return: 'More than any other task the Bank had undertaken, its engagement in Sub-Saharan Africa sapped the institution's ... confidence'. ${ }^{32}$ A primary reason for the failure of projects in the region, the Bank determined, was the highly adverse economic environment resulting from government policies. ${ }^{33}$ In a subsequent study of Africa's development, the World Bank set aside arguments based upon unforeseeable shocks, such as droughts, or external factors, such as declining terms of trade, and instead focused upon systematic and internal forces that lowered the rate of return on investments and the rate of growth of its economies. ${ }^{34}$ At the core of Africa's economic crisis, it argued still later, lay poor public policies and the lack of 'political will' to correct them. ${ }^{35}$

\section{Summary of Part I}

Qualitative and quantitative accounts thus posit a causal link between political accountability, the economic choices of governments and the performance of Africa's economies. But while many point out the political origins of Africa's development crisis, the arguments remain largely underspecified: in most cases, analysts either fail to identify the mechanisms linking political institutions to policy choices or to provide empirical support for their arguments. Building upon the work of Barro, Ferejohn, and Persson and Tabellini, we seek to fill this gap. ${ }^{36}$ We first develop the logic that links institutional and economic constraints on the one hand to policy choices on the other. We then test the arguments using data on political institutions (that come primarily from the World Bank's

31 D. Acemoglu, S. Johnson and J. A. Robinson. 'The Colonial Origins of Comparative Development: An Empirical Investigation', American Economic Review, 91 (2001), 1369-401. Note, however, that Acemoglu and Robinson do not analyse the political incentives to which particular institutions give rise - and that their measure of institutions is a measure of policy outputs rather than of formal political structures.

${ }^{32}$ D. Kapur, 'The Weakness of Strength: The Challenge of Sub-Saharan Africa', in D. Kapur, J. Lewis and R. Webb, eds, The World Bank: Its First Half Century (Washington, D.C.: The Brookings Institution, 1997), pp. 683-804, at p. 720 .

${ }_{33}$ World Bank, Accelerated Development in Sub-Saharan Africa: An Agenda for Action (Washington, D.C.: The World Bank, 1981).

${ }^{34}$ World Bank, Sub-Saharan Africa: From Crisis to Sustainable Growth (Washington, D.C.: The World Bank, 1989).

35 See, for example, World Bank, 'Adjustment in Africa - Reforms, Results, and the Road Ahead', World Bank Policy Research Bulletin, 5 (1994).

36 R. J. Barro, 'The Control of Politicians: An Economic Model', Public Choice, 14 (1973), 19-42; J. Ferejohn, 'Incumbent Performance and Electoral Control', Public Choice, 50 (1986), 5-26; T. Persson and G. Tabellini, Political Economics: Explaining Economic Policy (Cambridge, Mass.: MIT Press, 2000). See also C. Adam and S. O'Connell, 'Aid, Taxation, and Development in Sub-Saharan Africa', Economics and Politics, 11 (1999), 225-54; Ndulu and O'Connell, 'Governance and Growth in Sub-Saharan Africa'; and Bruce J. Bueno de Mesquita, J. Morrow, R. Siverson and A. Smith, 'Institutions, Outcomes and the Survival of Leaders' (Working Paper, Yale University, 2000). 
Research Department and from researchers at Harvard University) ${ }^{37}$ and data on public policy (that come from the ratings of private investment services and public institutions). ${ }^{38}$

\section{PART II: FROM POLITICAL INSTITUTIONS TO PUBLIC POLICY}

As others (see references above) have done, we seek to link policy choices to political institutions by casting the citizenry as a principal and the government as their agent. In this section, we establish this link by outlining the logic of political accountability. We provide a rigorous development in the Appendix and empirical tests in Part III.

Consistent with qualitative accounts of policy choices in Africa, our model takes a sceptical view of the motivations of governments. Governments, we assume, control public policy with a view to retaining office and enjoying the benefits of office. Through their policy choices, they induce the production of public goods - with which to enhance the public welfare - and private goods - with which to reward favoured citizens, or themselves. The value to a government of holding office is increasing in the value of the private goods that it can extract and consume. Being merely an agent, however, the government must apportion sufficient benefits to a sufficient number of citizens so that they will approve its return to office. Failing to secure that approval, the government must surrender power and re-enter the ranks of the citizenry.

Citizens serve as the government's principals. Subgroups of citizens are decisive in the sense that they can ensure the government's tenure in office. A democracy is marked by the fact that any majority is decisive. Alternatively, a smaller subset of the citizens may be decisive, as in the case of an oligarchy or personalistic regime.

We assume that the government lacks the means to commit itself to fulfilling its promises. The citizenry therefore discounts its pledges and instead focuses on its actual performance. That is, they evaluate its behaviour ex post. They are able to constrain the government's behaviour ex ante, however, by adopting a strategy that posits a target for the government: a level of benefits that the government must produce in order to be returned to office. Should the government meet the performance criterion of a decisive group, then this group can 'renew the government's contract'; should it fail, the group can then 'fire' the government. In so far as the strategies of members of decisive groups alter the policy choices of the government, the government is rendered accountable.

While citizens are backward looking, the government looks forward: it shapes its choices in an effort to retain public office. It adopts policies that enable it to maximize the private benefits it can extract through its use of public power. Under the constraints imposed by the economy, to maximize its private payoffs, the government seeks to satisfy the citizens by furnishing the lowest level of public goods and distributive benefits that will fulfil the performance standards of a decisive set of civilians. The mix of public and private goods chosen to meet any given standard depends on the structure of the economy. Governments find it more difficult to extract resources from economies in which resources are mobile

37 T. Beck, G. Clarke, A. Groff, P. Keefer and P. Walsh, 'New Tools and New Tests in Comparative Political Economy: The Database of Political Institutions' (Working Paper, The World Bank, 2000); Karen Ferree and Smita Singh, 'Political Institutions and Economic Growth in Africa: 1970-1995', in Steve Chan and James Scarritt, eds, Coping with Globalization: Cross-National Patterns in Domestic Governance and Policy (Boulder, Colo.: Frank Cass, 2002), pp. 89-120.

${ }^{38}$ Political Risk Services, International Country Risk Guide (dataset available on-line at http:// www.countrydata.com/wizard/); see also discussion of the World Bank's 'Country Policy and Institutional Assessment' measure below. 
than they do from economies in which resources are immobile. They are therefore driven to exchange public benefits for tax revenues in the first to a greater degree than in the second kind of economy.

Political accountability thus renders the government an agent and the citizens its principal. But the interests of the two are not fully aligned: the government possesses private interests of its own and is therefore a less than perfect servant of the citizenry. The relationship between the government and the citizens thus takes on the properties of a game. In this game, the citizens move first, choosing a minimum level of acceptable performance by their government. Knowing how the citizens have chosen, the government then chooses public policies, seeking to gain the maximum private benefits from office that are consistent with re-selection. After its term has been completed, the citizens evaluate the government's performance. If some decisive group of citizens approves, it may choose to renew the government's contract. The game between the citizens and their government is played over an infinite number of periods of fixed length; each player's valuation of utility is given by the sum of welfare in each period, discounted for time.

As set out in the Appendix, there exists an equilibrium for this game in which the strategy followed by citizens compels the government to produce more public goods and fewer private benefits for itself than it might otherwise desire. The Appendix thus provides a formal theory of the political foundations of policy choice, demonstrating how institutions of accountability generate incentives that influence public policy in ways that enhance the collective welfare.

The logic of accountability yields several empirical implications. Some flow immediately from the standard models, as advanced by Barro, Ferejohn, and Persson and Tabellini (see footnote 36). First, for the logic to hold, governments should face competitive electoral processes. The more competitive the electoral process, the greater the level of public goods that governments are required to provide in order to remain in office. Secondly, for the ex post judgements of citizens to generate ex ante incentives for policy decisions, the government must be forward looking. The government's discount rate - i.e. the rate at which it discounts payoffs or penalties occurring in later periods of time - should therefore affect its behaviour. Should a government occupy an unstable regime or face the risks of regime collapse, then it will tend to discount more highly than would a government that is more secure with respect to the future impact of present policy choices.

Note that risk therefore plays a complex role: governments that are at risk of political rejection conditional upon their performance within stable institutional environments possess incentives to adopt public policies that are collectively rather than privately beneficial. But governments that are at risk as a function of exogenous sources of instability possess weak incentives.

The argument we advance (see Appendix) contains two additional, non-standard features, however, and these yield additional implications. One concerns the size of the decisive sets. Governments, according to our model, seek to gain office at least cost; they seek to maximize the benefits of office holding by minimizing the resources they must divert to powerful citizens. All else being equal, the larger the set of citizens that a government must satisfy, the less efficient is the use of private transfers to satisfy clients. ${ }^{39}$ These considerations imply that the larger the size of the decisive sets, the less the

\footnotetext{
39 Persson and Tabellini, Political Economics, provide a discrete version of this result in order to characterize differences between proportional representation (PR) and non-PR systems.
} 
government will extract for itself and the more inclined it will be to recruit political support by providing public goods rather than distributive benefits. Secondly, according to our model, the nature of the economy influences the policy choices of governments. If resources are mobile, then the costs of redistribution are high; the owners of assets will shift them to activities that elude taxation. It thus becomes more difficult for governments to use extractive policies to retain the support of decisive groups. Conversely, if resources are fixed as, for example, in the case of economies that are heavily dependent on natural resources, then the implication of our model, is that governments will be more inclined to use public policy to appropriate private benefits rather than to generate public goods.

The Appendix provides formal proofs of these arguments.

\section{PART III: EMPIRICAL TESTING}

The logic of accountability thus yields empirical propositions, rendering the arguments subject to testing. To test these propositions, we assembled data on political institutions and economic structures in Africa and from a global sample of countries. As is standard, we fully capitalize the variable names; their definitions appear in Table 5.

TABLE 2 Country Policy and Institutional Assessments (CPIA)

Disaggregated elements of CPIA Index

I. Macroeconomic management

1. General macroeconomic performance

2. Fiscal policy

3. Management of external debt

4. Macroeconomic management capacity

5. Sustainability of structural reforms

II. Public sector management

1. Quality of budget and public investment process

2. Efficiency and equity of resource mobilization

3. Efficiency and equity of public expenditures

4. Accountability of the public service

III. Policies for sustainable and equitable growth

1. Trade policy

2. Foreign exchange regime

3. Financial stability and depth

4. Banking sector efficiency and resource mobilization

5. Property rights and rule-based governance

6. Competitive environment for the private sector

7. Factor and product markets

8. Environmental policies and regulations

IV. Policies for reducing inequalities

1. Poverty monitoring and analysis

2. Pro-poor targeting of programs

3. Safety nets

Rating scale: $1=$ low; $5=$ high

Source: 'Country Policy and Institutional Assessments', Report on 1998 Ratings (Washington, D.C., World Bank, 1988). 


\section{Dependent Variables}

To study the impact of institutions on policy choices, we employ two measures. Both reflect the assessments of informed observers. The first comes from the International Country Risk Guide (ICRG) produced by Political Risk Services (PRS) and is derived from scores given by a panel of international investors. ${ }^{40}$ Each year, the panel rates governments on a series of dimensions, each capturing elements of political, economic and financial risk to investors. For each country, our measure, QUALITY, combines ratings of the government's propensity to engage in corruption and the government's likelihood of engaging in expropriation. To produce the measure, we weight these two ratings by the loading derived from principal components estimation. The resulting score provides a measure of the tendency to adopt distributive policies and to make opportunistic use of public power.

We also employ the World Bank's Country Policy and Institutional Assessment (CPIA), an annual evaluation of the conduct of governments that have loans outstanding with the Bank. The CPIA provides a measure of the World Bank's evaluations of governments' efforts to generate a sustainable macro-economic environment, free of major policy distortions. It is in fact the main measure used in the recent and influential literature on aid effectiveness, where it measures the extent to which governments provide publicly regarding policies. ${ }^{41}$ The Bank's rating covers the policy performance of the government in twenty specific areas, grouped into four major categories (see Table 2). Scoring the country's performance in each area from 1, for low, to 5, for high, the Bank calculates an aggregate score, or CPIA, which is the unweighted average of the rating in each of the twenty areas.

It is important to realize that the CPIA, while informative, is flawed. ${ }^{42}$ The CPIA measures deviation from the set of policies that make up the so-called Washington

\begin{tabular}{lccc} 
TABLE 3 & $\begin{array}{c}\text { Summary Statistics for Dependent } \\
\text { Variables }\end{array}$ \\
\hline \hline Variable & SSA & $\begin{array}{c}\text { Rest of the } \\
\text { world }\end{array}$ & World \\
\hline QUALITY & -0.53 & 0.18 & 0 \\
& $(0.59)$ & $(0.95)$ & $(1.0)$ \\
CPIA & 2.64 & 3.00 & 2.9 \\
& $(0.74)$ & $(0.71)$ & $(0.74)$ \\
\hline
\end{tabular}

Note: This table reports the average scores for sub-Saharan Africa and the rest of the world for each of the two dependent variables. Standard deviations of the sample distributions are reported in parentheses.

${ }^{40} \mathrm{http}: / / \mathrm{www}$. countrydata.com/wizard.

${ }^{41}$ See, for example, Paul Collier and David Dollar, 'Aid Allocation and Poverty Reduction', European Economic Review, 46 (2002), 1475-500.

${ }^{42}$ Regressing the aggregate score against measures of macro-economic balances - levels of government consumption, fiscal deficits, inflation and so on - shows the measure to yield highly significant relationships with objective measures of policy choices and enhances our confidence in the measure. There are, however, some technical concerns with the measure: it mixes assessments of policies with outcomes and it assigns equal weights to each policy. The measure is both bounded and categorical, resulting in a distribution of errors that could complicate statistical inference. Furthermore, there is evidence that the criteria for determining the score have 
TABLE 4 Growth and Policy Choice

\begin{tabular}{|c|c|c|c|c|}
\hline \multirow[b]{2}{*}{ Dependent variables } & \multicolumn{2}{|c|}{ SYSTEM 1} & \multicolumn{2}{|c|}{ SYSTEM 2} \\
\hline & Growth & QUALITY & Growth & CPIA \\
\hline QUALITY & $\begin{array}{l}1.248 \\
(3.12)^{* * *}\end{array}$ & & & \\
\hline CPIA & & & $\begin{array}{l}1.757 \\
(2.52) * *\end{array}$ & \\
\hline GDP growth (annual \%) & & $\begin{array}{l}0.085 \\
(7.20)^{* * *}\end{array}$ & & $\begin{array}{l}0.09 \\
(8.21)^{* * *}\end{array}$ \\
\hline Per capita GDP (lag) & $\begin{array}{l}-1.682 \\
(5.54)^{* * *}\end{array}$ & $\begin{array}{l}0.105 \\
(10.67)^{* * *}\end{array}$ & $\begin{array}{l}-2.132 \\
(6.48)^{* * *}\end{array}$ & $\begin{array}{c}0.186 \\
(10.05)^{* * *}\end{array}$ \\
\hline $\begin{array}{l}\text { Gross Domestic Investment } \\
\text { as a share of GDP }\end{array}$ & $\begin{array}{l}12.045 \\
(7.88) * * *\end{array}$ & & $\begin{array}{l}8.327 \\
(7.34)^{* * *}\end{array}$ & \\
\hline Life expectancy (logged) & $\begin{array}{l}11.037 \\
(4.41)^{* * *}\end{array}$ & & $\begin{array}{l}13.597 \\
(5.54)^{* * *}\end{array}$ & \\
\hline Literacy rate & $\begin{array}{l}-0.019 \\
(2.09) * *\end{array}$ & & $\begin{array}{l}-0.026 \\
(2.86)^{* * *}\end{array}$ & \\
\hline Literacy $\times$ GDP & $\begin{array}{c}0 \\
(2.80) * * *\end{array}$ & & $\begin{array}{l}0 \\
(3.39)^{* * *}\end{array}$ & \\
\hline $\begin{array}{l}\text { General government } \\
\text { consumption (\% of GDP) }\end{array}$ & $\begin{array}{l}-0.075 \\
(3.44) * * *\end{array}$ & & $\begin{array}{l}-0.085 \\
(3.41)^{* * *}\end{array}$ & \\
\hline Sub-Saharan Africa & $\begin{array}{l}1.027 \\
(2.04)^{* *}\end{array}$ & & $\begin{array}{l}1.455 \\
(2.88) * * *\end{array}$ & \\
\hline COMPETITIVENESS & & $\begin{array}{l}0.031 \\
(3.58)^{* * * *}\end{array}$ & & $\begin{array}{l}-0.024 \\
(2.34)^{* *}\end{array}$ \\
\hline CHECKS & & $\begin{array}{c}0.023 \\
(1.83)^{*}\end{array}$ & & $\begin{array}{l}0.054 \\
(3.49)^{* * *}\end{array}$ \\
\hline AGRIPOP (Lag) & & $\begin{array}{r}-0.225 \\
(1.94)^{*}\end{array}$ & & $\begin{array}{l}0.359 \\
(2.69)^{* * *}\end{array}$ \\
\hline PROBLEM (Lag) & & $\begin{array}{l}-0.195 \\
(5.50)^{* * *}\end{array}$ & & $\begin{array}{r}-0.07 \\
(1.64)\end{array}$ \\
\hline OIL & & $\begin{array}{l}-0.442 \\
(2.64)^{* * *}\end{array}$ & & $\begin{array}{l}-1.068 \\
(5.37)^{* * *}\end{array}$ \\
\hline Year & & $\begin{array}{c}0.07 \\
(14.39)^{* * *}\end{array}$ & & $\begin{array}{l}0.012 \\
(2.81)^{* * *}\end{array}$ \\
\hline Constant & $\begin{aligned}- & 41.588 \\
& (4.14)^{* * *}\end{aligned}$ & $\begin{aligned}- & 140.402 \\
& (14.47)^{* * *}\end{aligned}$ & $\begin{array}{l}-56.211 \\
(6.29)^{* * *}\end{array}$ & $\begin{array}{l}-21.459 \\
(2.56) * *\end{array}$ \\
\hline Observations & 973 & 973 & 1,109 & 1,109 \\
\hline
\end{tabular}

Notes: Absolute value of $z$ statistics in parentheses. *Significant at $10 \%$; **significant at $5 \%$; ***significant at $1 \%$. The models have been jointly estimated using three-stage least squares (World sample). These models differ from Barro's standard model in a number of ways. First, annual data is used rather than quinquennial data. Secondly, for reasons of data coverage, less rich education data is used: Literacy $\times$ GDP is related to Barro's interaction between GDP and human capital where literacy substitutes for Barro's aggregate human capital measure. Finally, in the context of this article, our measures of QUALITY and CPIA substitute for Barro's measure of market distortions, given by a measure of the black-market premium.

(F'note continued)

varied over time. Note that while the CPIA index is based in part on assessments of institutions, (a) these assessments constitute but a minor portion of the total rating and (b) were the Bank raters inclined to give higher ratings to countries that exhibited higher levels of political accountability, then this would bias us towards finding such a positive correlation in the data, contrary to what we in fact find (see below). 


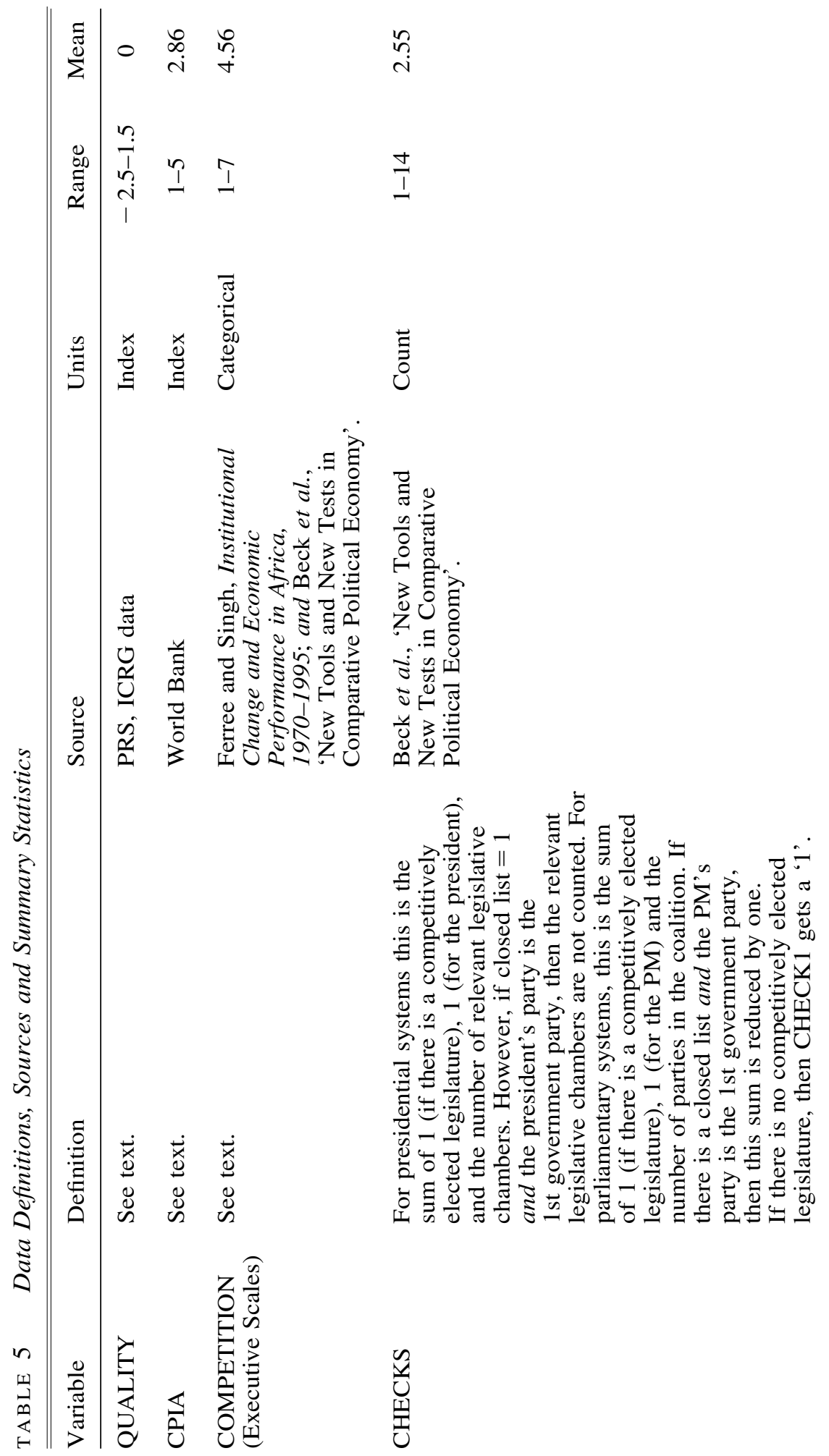



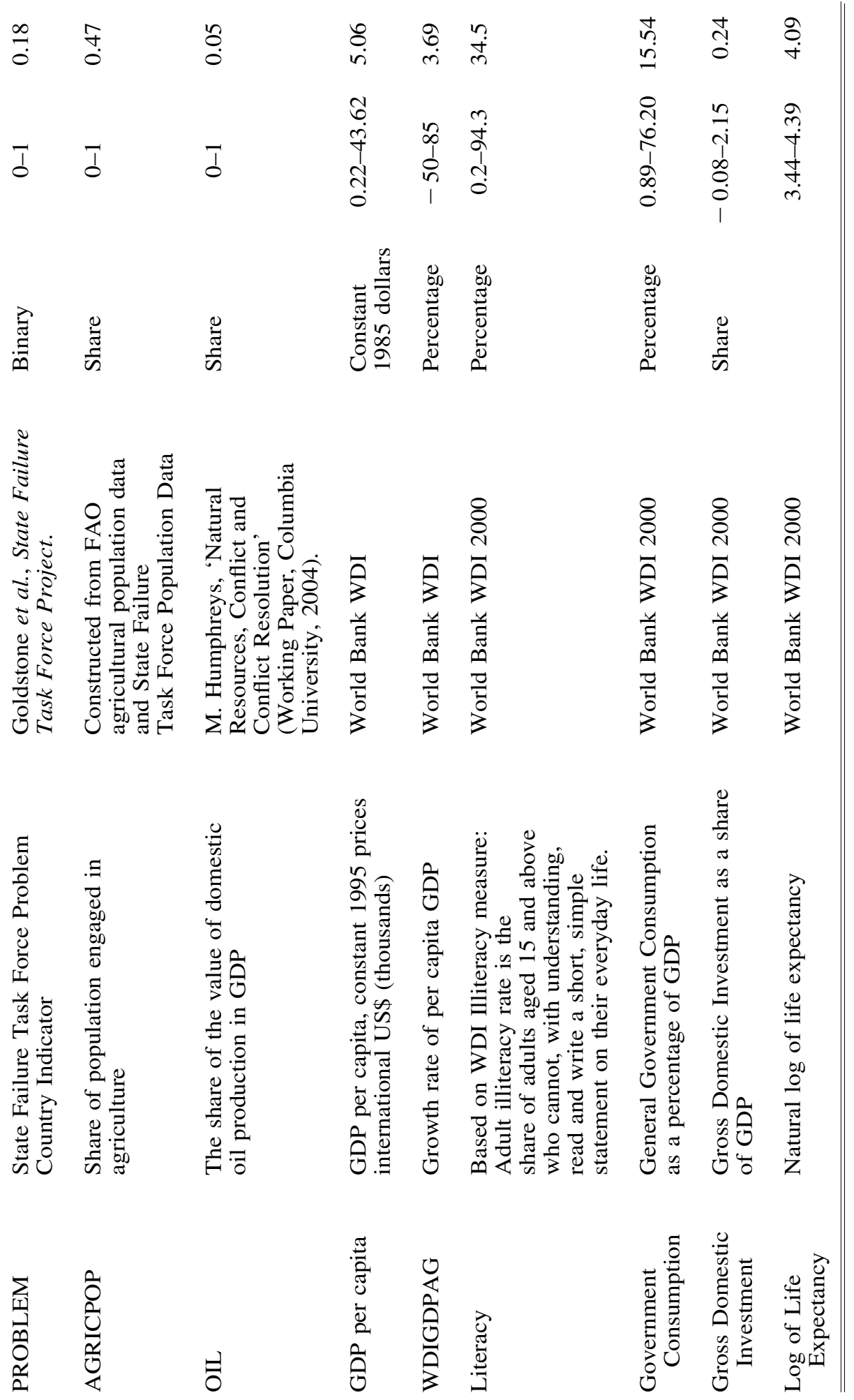
Consensus. ${ }^{43}$ The extent to which the measure captures policies deemed of 'social benefit' is open to challenge: while the World Bank may believe that these policies generate public benefits, these views are not universally held in Africa. ${ }^{44}$ As can be seen from the data contained in Table 3, the policy choices of governments in Africa are rated by investors and the World Bank more negatively than are the choices of governments in the rest of the world.

Multiple studies find strong relationships between such measures and economic growth rates. ${ }^{45}$ In Table 4, we provide further evidence that this relationship obtains for the two dependent variables - QUALITY and CPIA - and for our sample. ${ }^{46}$ By combining a Barro-like growth regression (which includes the policy ratings) with an empirical model of policy choice (which includes a measure of growth and other controls, see Table 5) into a single system of equations using three-stage least squares ${ }^{47}$ we generate coefficients that provide measures of the relationship of policy to growth that partially account for endogeneity. These results indicate that variation in our measures of policy choices are associated with large differences in growth rates: a one standard deviation shift in QUALITY and CPIA is associated with a shift of approximately 1.2 and 1.3 percentage points in growth rates, respectively. Tables 3 and 4 thus highlight the significance of our exploration into the institutional determinants of policy decisions.

\section{Independent Variables}

The measures of the independent variables come from the files of the Africa Research Program (ARP) at Harvard University, ${ }^{48}$ the Database on Political Institutions (DPI) compiled by Beck et al. and data released by the World Bank. ${ }^{49}$ Table 5 reports the definitions and distributions of these variables and the sources from which they were drawn.

In describing these variables and our expectations of their relationship to measures of policy performance, we proceed in a sequence that parallels our exposition of the logic of political accountability, first dwelling on institutions, then on the determinants of the

\footnotetext{
43 See John Williamson, 'What Washington Means by Policy Reform', in John Williamson, ed., Latin American Adjustment: How Much Has Happened? (Washington, D.C.: Institute for International Economics, 1990), pp. 7-20; also John Williamson, ed., The Role of Technocrats in Economic Policy Reform (Washington, D.C.: Institute for International Economics, 1994).

${ }^{44}$ There is less doubt concerning the desirability of lower levels of expropriation. The simple correlation between the two dependent variables is 0.56. See W. Easterly, The Elusive Quest for Growth (Cambridge, Mass.: MIT Press, 2001); see also J. Stiglitz, Globalization and its Discontents (New York: W. W. Norton, 2002).

${ }^{45}$ For a study employing the World Bank's measure, see Collier and Dollar, 'Aid Allocation and Poverty Reduction'. For a study of economic growth with Political Risk Services data on the right-hand side, see Acemoglu, Johnson and Robinson, 'The Colonial Origins'.

${ }^{46}$ Indeed each of these measures has appeared as an explanatory variable in growth regressions elsewhere. For a study employing the World Bank's measure, see Collier and Dollar, 'Aid Allocation and Poverty Reduction'. For a study of economic growth with Political Risk Services data on the right-hand side, see Acemoglu, Johnson and Robinson, 'The Colonial Origins'.

47 The variables used in this table are described below. See Table 5 for summary statistics.

48 http://africa.gov.harvard.edu.

49 Beck et al., 'New Tools and New Tests in Comparative Political Economy'; World Bank, World Development Indicators (Washington, D.C.: Oxford University Press, 2000).
} 
governments' discount rate, then on the nature of the decisive sets, and finally on the structure of the economy.

Institutions: According to the logic of accountability, the incentives that drive government responses bite because the government faces the prospects of ejection from office. To bring the logic to bear on debates over the role of electoral competition in economic reform, especially in Africa, we employ a measure of electoral COMPETITION. By the rules governing the creation of this measure, a polity receives a score of 1 if there is no executive in place; 2 if there is a non-elected executive; 3 if there is an elected executive but no electoral competition; 4 if there is an elected executive, and competition between candidates but not between parties (because opposition parties are banned); 5 if there is an elected executive and competition between candidates but not between parties (even though opposition parties are legal); and 6 if there is an elected executive, with competition between candidates backed by opposing parties taking place during the electoral campaign. A score of 7 is accorded in the DPI if the executive's vote share is less than 75 per cent.

Discount rate. As argued above, the strength of the incentives to which institutions of accountability give rise depends upon the government's rate of discount. Affecting the value the government places upon future benefits from office is its assessment of political risk. To capture the level of political risk arising from political instability, we employ a measure of the instability of a given regime developed by the State Failure Task Force. ${ }^{50}$ This measure - which we call PROBLEM - indicates whether each country was a part of the State Failure Task Force's 'problem set' in the previous year by virtue of being embroiled in a civil conflict, undergoing extreme levels of violence or experiencing an adverse regime change. ${ }^{51}$ As a secondary indicator we also employed a measure of the predicted likelihood of being within the task force Problem Set conditional upon past information for any point in time.

Properties of the decisive sets. According to the logic of the model, the degree to which a government will employ political power to produce collective benefits depends upon the size of the decisive sets. The larger the number of veto points within the institutions of government, the more inclusive the decisive set must be. The logic of the model therefore suggests that the larger the number of veto points in the institutions of government, the more likely will policy makers be to promote the creation of collective goods. The variable, CHECKS, is based upon the number of independent parts of the political process. It uses information regarding the number of different parties in a governing coalition and the extent to which there is a competitive legislature independent of the president or prime minister's party. ${ }^{52}$

Economic structures. As captured in the model provided in the Appendix, policy makers are constrained by the types of economies in which they function. In particular, if economic

\footnotetext{
50 J. Goldstone et al., State Failure Task Force Project, Phase III Report (McLean, Va.: SAIC, 2003).

${ }^{51}$ More information on this measure can be found on the homepage of the State Failure Task Force: http://www.cidcm.umd.edu/inscr/stfail/sfcodebk.htm.

52 Each of the DPI variables, CHECKS1 and CHECKS2 were used in the analysis. See the Appendix for a full definition of these variables.
} 
agents are able to protect themselves from predation by reducing production or by moving their assets, then extractive policies will yield fewer benefits to government.

We use two variables to capture the ease with which rents can be extracted. The first, AGRICPOP, measures the share of the population that is dependent upon agricultural production. The second, OIL, measures the value of oil production as a share of the gross domestic product (GDP). In each case we expect negative relations between these measures of economic structure and performance on the dependent variable.

Table 6 presents data from the Africa sample on key variables in the analysis. As might be expected, Botswana and South Africa receive the highest ratings from private investors; they also exhibit the highest average level of political competition. As also might be expected, the Democratic Republic of Congo receives the lowest rating from private investors as well as one of the lowest average levels of political competition. Some - such as Namibia - exhibit highly negative ratings on one dimension but highly positive scores on the other. Most exhibit investor ratings that place them significantly below the global average and reflect an absence of political competition.

TABLE $6 \quad$ Countries Included in Estimates in Tables 7 and 8

\begin{tabular}{lcc}
\hline \hline COUNTRY & Average & Average \\
QUALITY & COMPETITION \\
\hline Botswana & 0.4 & 6.0 \\
South Africa & 0.3 & 6.5 \\
Gabon & 0.3 & 3.4 \\
Cote d'Ivoire & 0.2 & 3.7 \\
Gambia, The & 0.1 & 6.6 \\
Tanzania & -0.1 & 3.0 \\
Cameroon & -0.1 & 3.5 \\
Malawi & -0.2 & 2.2 \\
Kenya & -0.2 & 3.1 \\
Ghana & -0.3 & 3.2 \\
Mozambique & -0.3 & 2.7 \\
Togo & -0.3 & 3.0 \\
Senegal & -0.4 & 5.8 \\
Zimbabwe & -0.4 & 6.3 \\
Guinea & -0.4 & 3.0 \\
Ethiopia & -0.5 & 2.0 \\
Zambia & -0.6 & 3.9 \\
Niger & -0.6 & 2.7 \\
Nigeria & -0.7 & 3.0 \\
Sierra Leone & -0.7 & 2.8 \\
Burkina Faso & -0.7 & 2.6 \\
Angola & -0.8 & 3.3 \\
Republic of Congo & -0.8 & 2.4 \\
Uganda & -0.9 & 3.2 \\
Guinea-Bissau & -0.9 & 2.7 \\
Namibia & -0.9 & 6.8 \\
Madagascar & -1.1 & 4.8 \\
Mali & -1.2 & 3.2 \\
Democratic Republic & -1.3 & 2.9 \\
$\quad$ of Congo & & \\
\hline \hline
\end{tabular}


Restriction on the use of the Country Policy and Institutional Assessments prevents the reporting of these data for specific countries.

\section{Control Variables}

We include a small set of variables to control for the impact of the wealth of the country, GDP growth rates and time. We also add an Africa dummy in the pooled regressions that employ the global dataset. This variable provides an important check on our argument. For if our reasoning provides an adequate theory of the policy preferences of Africa's governments, then the coefficient on the African dummy should fail to attain statistical significance, when the variables that capture the logic of accountability are entered into the analysis. ${ }^{53}$

\section{Estimation}

We first estimate our statistical models using a pooled sample of observations. We then re-estimate each model introducing country-specific effects and the lag of the dependent variable. Since a fixed-effects structure that includes a lagged dependent variable may introduce bias in finite samples, ${ }^{54}$ we report a third version of each model that employs the Arrelano and Bond Generalized Method of Moments estimator. ${ }^{55}$

\section{Results and Discussion}

In Tables 7 and 8 below, we present two sets of results. Table 7 presents results for QUALITY for both an African and a world sample. Table 8 presents similar results for CPIA. In the case of QUALITY, the analysis is based upon data from 103-4 nations, of which 28-9 are from Africa, depending on data availability; the samples cover the period 1985-95. In the case of CPIA, the global sample includes 95-6 nations and the African sample 36-7 and both cover the period 1975-90.

We interpret positive coefficients for the variables relating to QUALITY as suggesting that higher levels of the variable yield a lower tendency for the government to employ public powers to extract private benefits from the economy. In the case of CPIA, we interpret positive coefficients as suggesting that higher levels of the independent variable yield a stronger tendency on the part of governments to use public policy to generate a stable macro-economic environment.

Turning first to the control variables, we note a pronounced tendency for hysteresis in

\footnotetext{
53 We stress that the results presented here do not take account of the possible impact of policy on the supposedly independent variables. Our results are robust to the replacement of independent variables with their lags; however, save in the estimates reported in Table 3, we have yet to model these endogenous relationships directly. We note however that in so far as public goods provision, as recorded by the World Bank, may increase the competitiveness of institutions, this should lead to an upward bias in the estimated correlation, and hence, a bias against our result.

54 Jeffrey M. Wooldridge, Econometric Analysis of Cross Section and Panel Data (Cambridge, Mass.: MIT Press, 2002).

${ }_{55}^{5}$ M. Arellano and S. Bond, 'Some Tests of Specification for Panel Data: Monte Carlo Evidence and an Application to Employment Equations', Review of Economic Studies, 58 (1991), 277-97. The results reported do not take account of the categorical and censored nature of the dependent variable. While formally categorical, the dependent variables in fact contain as many as thirty values. And although formally bounded, there is little clustering of data on the boundaries. We therefore find that employing Tobit models made little impact on our estimates.
} 


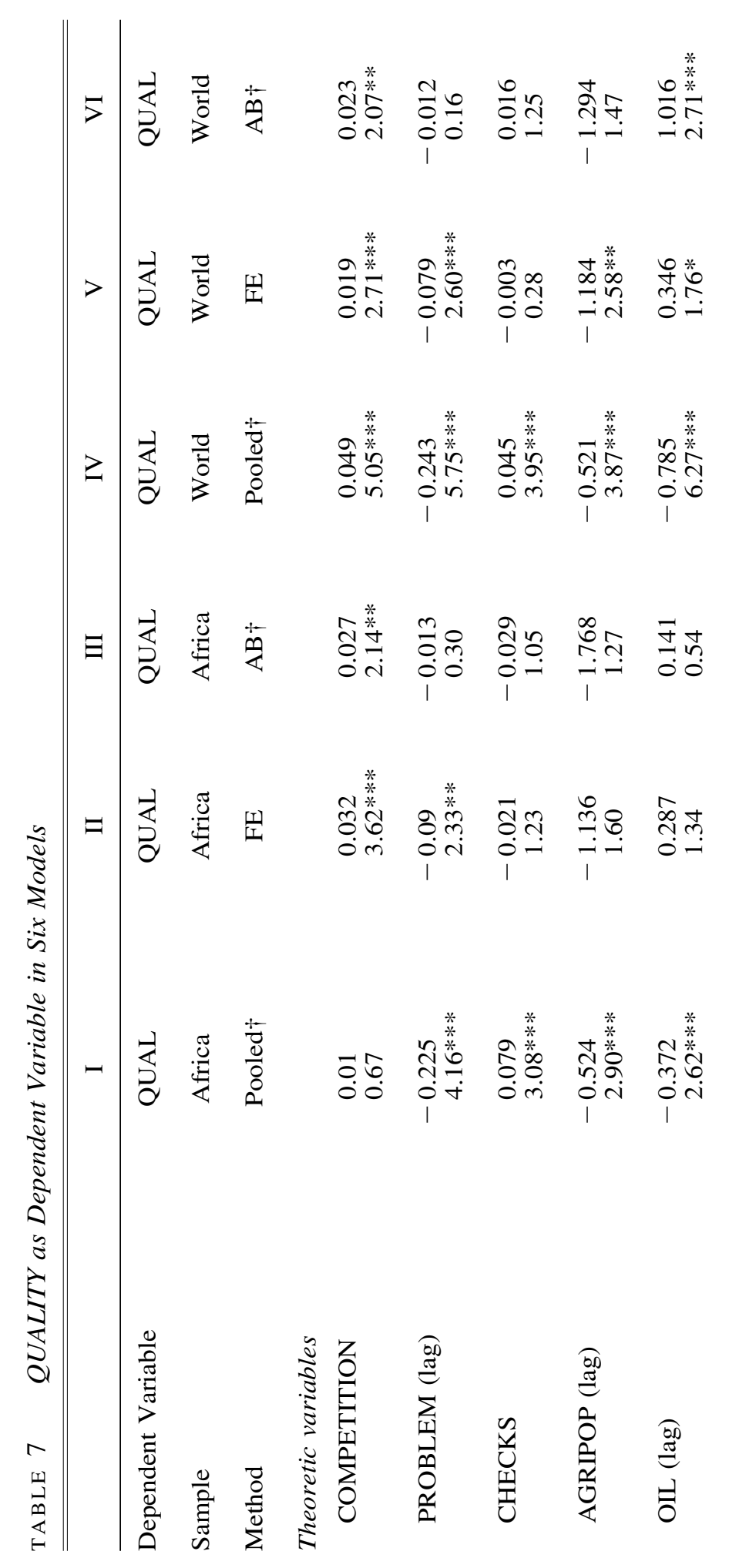


1.

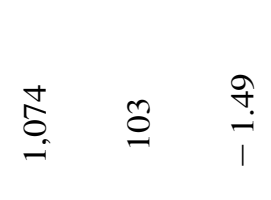

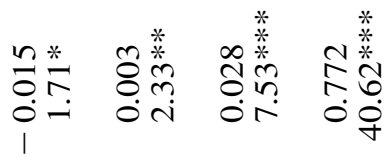

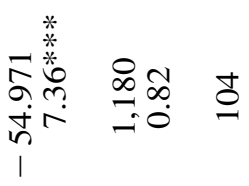

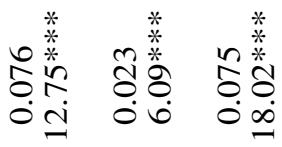

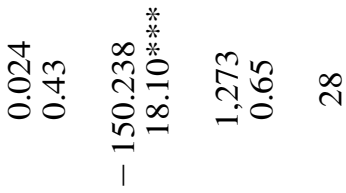

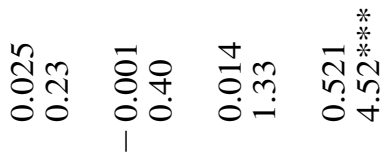

ळે

\|

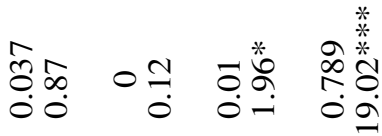

至

잉

桲

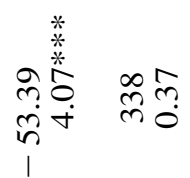

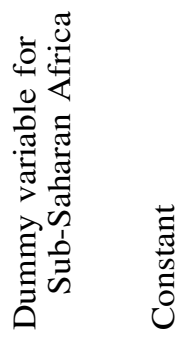

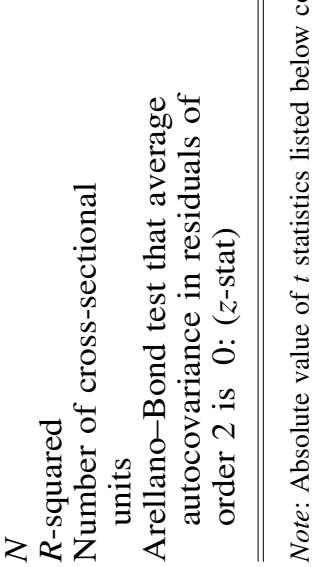




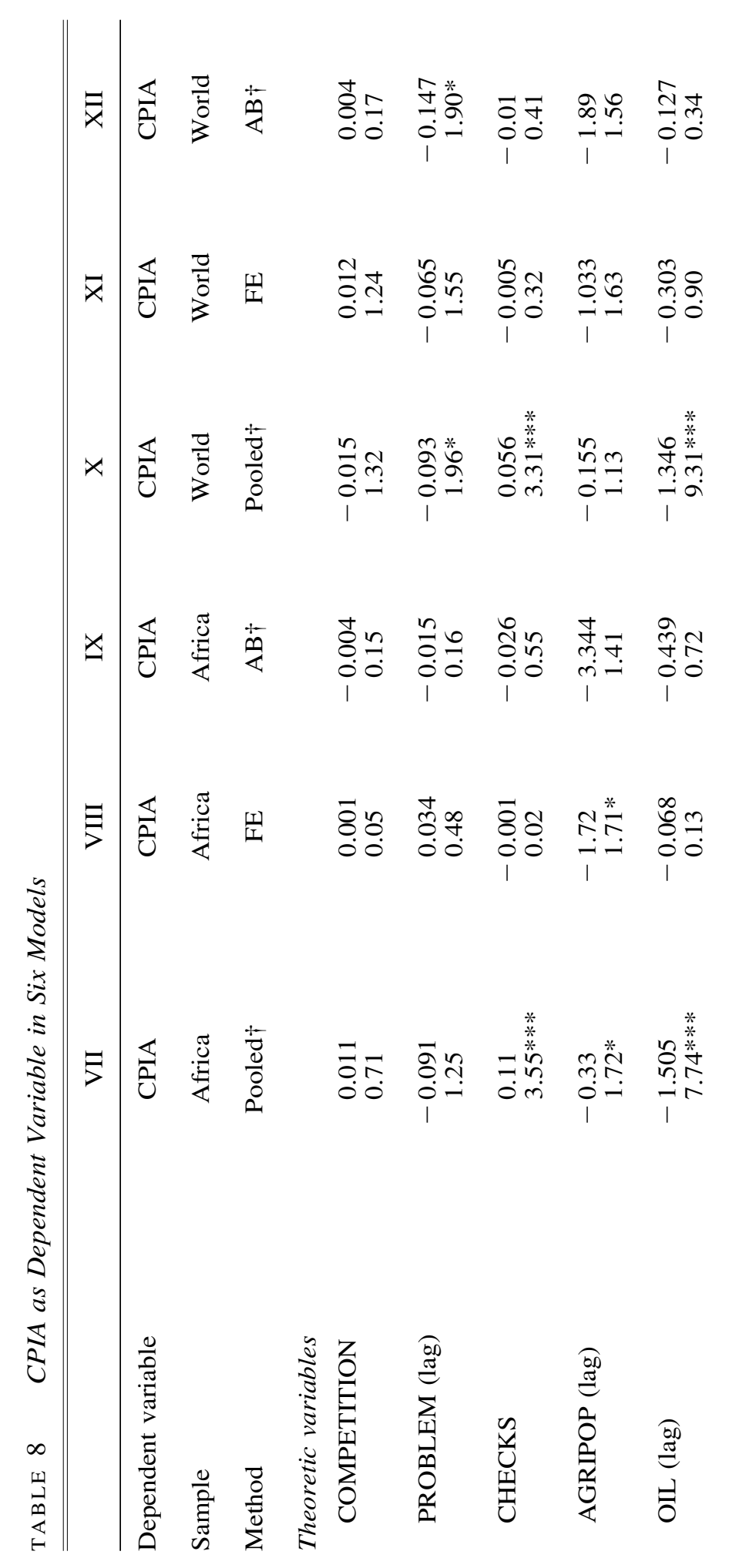




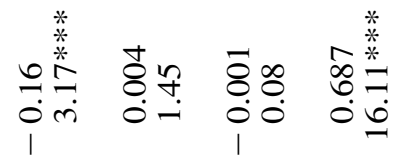

$$
\text { gे n }
$$

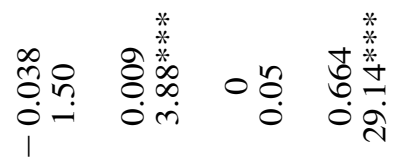

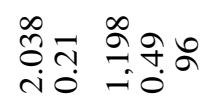

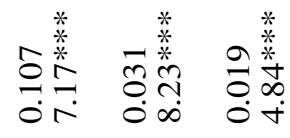

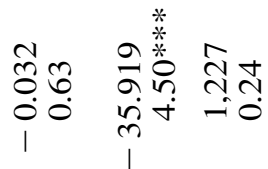

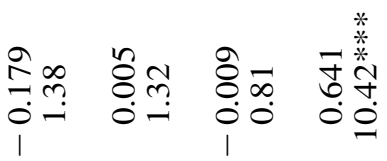<smiles>O=S1(=O)C=CC=C1</smiles>

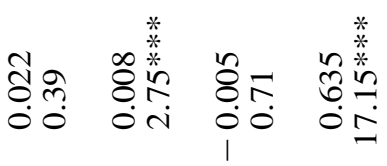

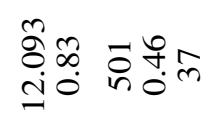

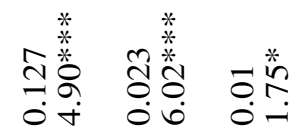

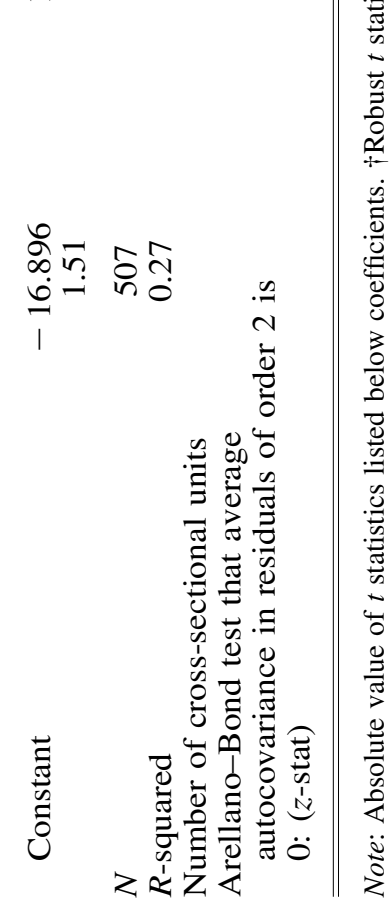

$$
\frac{\frac{0}{0}}{\frac{\pi}{3}}
$$

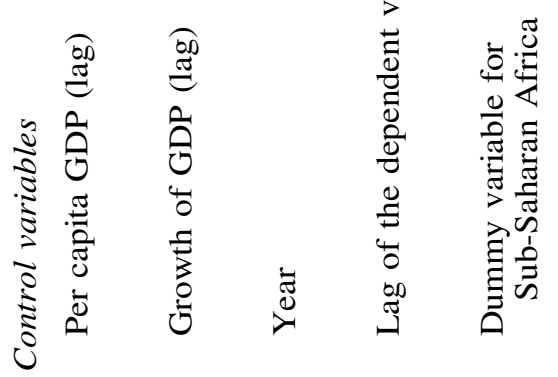


public policy: the magnitude and significance of the coefficients on the lagged dependent variables indicate that policies, once chosen, tend to persist. As expected, wealth and GDP growth are associated with more favourable policy ratings, although we are reluctant to give a causal explanation to this correlation.

Turning to the theoretically imortant variables:

Institutions. According to debates over political reform in Africa and to the logic of our argument, the spur to self-restraint originates from the risks inherent in reselection.

When using QUALITY as a measure of policy choice, we encounter the expected results (Models I-VI). Both the African and global samples offer evidence of a relationship between electoral competition and policy performance. These results are strongly significant in all but one specification. The magnitudes of the coefficients suggest that an increase in competitiveness from the lowest to the highest value is associated with an increase in the QUALITY score of approximately a fifth of a standard deviation. Based on the estimates contained in Table 4, this magnitude of policy change implies an increase in the growth rate of approximately a quarter of a percentage point.

We find however that when we use the CPIA as a measure of policy choice, then there is no evidence for a relation between institutions and policy choice, once we control for the impact of other factors. Indeed, in some models there is (weak) evidence that, when subject to the spur of electoral competition, governments choose policies that distort the macro economy (Models XI and XII).

Discount rate. The data provide evidence of the impact of discounting. If a government is sufficiently unstable to fall into the State Failure Task Force's problem set (i.e. PROBLEM = 1), the policy environment deteriorates for private investors, as measured by QUALITY (Table 7). The same relationship holds, but more weakly, for the World Bank ratings of government policies in the global sample. Higher levels of regime instability tend to associate with opportunistic policy making. The magnitudes in Models I, II, IV and V associate instability with a fall in QUALITY of between a tenth and a fifth of a standard deviation.

Decisive groups. The formal model underscores the importance of a third set of variables: those relating to the size of the decisive coalitions. The larger the size of its core constituency, the logic suggests, the stronger the incentives for the government to reward it through the production of public goods.

The pooled regressions suggest that governments that face multiple veto points - i.e. that are constrained by checks and balances - adopt policies that elicit higher ratings. This is true for both dependent variables and for both samples in the pooled regressions, but the relationship is not observed when modelled using fixed effects. These institutional features are 'slow moving', however. Possibly for that reason, measures of their impact fail to emerge in the equations that use differenced values of the variables.

The nature of the economy. When corrected for bias arising from the incidence of a lagged dependent variable, there is scattered evidence in the Africa sample that increases in the importance of primary products in the private economy lead to the adoption of self-interested policies.

When OIL is employed as a measure of resource mobility, the results for the pooled 
regressions support the hypothesized relationship between the costs of private goods extraction and the choices of governments. The equations that employ differenced data do not, however; and the coefficient of OIL in one such equation - that in the global sample, using QUAL as a dependent variable and GMM methods of estimation - yields evidence against our argument.

More consistent is the evidence of the impact of agriculturally dependent populations: governments in countries in which the population is largely agricultural tend to adopt more distributive policies. The sign on our measure of agricultural populations is negative in all samples and for both dependent variables. It fails to attain significance in all models, however, particularly those employing the Arrelano and Bond estimator.

While weak, the evidence for a relationship between factor mobility and policy is important in its own right. It underscores that when attempting to explain the policy choices of governments, we should look not only at the proclivities of political elites and the institutional constraints under which they labour, but also at the structure of the economies that they govern. ${ }^{56}$ Given that Africa's economies are largely agricultural in nature, and that the most valuable industries are based on resource extraction, its governments face fewer costs when themselves engaging in extractive policies, and therefore face fewer incentives to refrain from predatory policy making.

Lastly, we note that the African dummy in the global sample in Tables 7 and 8 have insignificant coefficients. Viewed within the perspective of our model of policy choice, African governments behave in ways that are indistinguishable from governments elsewhere.

\section{CONCLUSION}

Employing a simple theoretically driven model, we have identified properties of national economies and political institutions that significantly influence policy choices by African governments. Some are economic. Governments whose economic base is immobile are more likely to engage in predation. Others are political. Africa is wracked with political instability and private investors find unstable governments to behave more opportunistically. Governments subject to checks and balances behave with greater restraint than do those less constrained, the data suggest. And, in the case of measures developed for private investors, governments that are subject to electoral competition are more likely to employ public power to produce collective goods rather than to extract private benefits. Given the evidence from Table 4, these differences matter: governments whose economic and political endowments predispose them to choose 'better' policies tend to secure higher rates of economic growth.

We must emphasize, however, that the magnitude and significance of these effects vary considerably by specification and as a function of the samples and equations employed. After controlling for core determinants of policy choice (i.e. those derived from qualitative accounts and formal theory) we find that much of the variation in policy choices in Africa still remains unaccounted for.

In closing, we wish to draw attention to a striking anomaly. While the relation between competitive institutions and the data from private investor ratings consistently conforms

\footnotetext{
${ }^{56}$ In so far as the structures of economies are themselves a function of the policy choices of governments and subsequent growth rates, this analysis suggests the possibility of multiple equilibria, with some economies residing in a low-output high-extraction equilibrium and others dwelling in a high-output low-extraction equilibrium.
} 
to the logic of accountability, the relationship with the World Bank ratings of policy performance does not. The first row of Table 8 is singularly devoid of significant coefficients: we fail to find any evidence that competitive electoral processes are positively associated with policy choices as advocated by the World Bank.

The most direct interpretation of this result is that the results reflect the political unpopularity of stabilization policies. ${ }^{57}$ Our empirical estimates represent a test of the model of accountability only if citizens favour the kind of non-distortionary policies rated highly by the World Bank. But evidence from Afrobarometer surveys indicate that while African populations support some micro-economic reforms (such as the introduction of user fees), they do not favour adjustments that accompany the tightening of macroeconomic policies. ${ }^{58}$ Rather than regarding these adjustments as providing a public good, they view them as benefiting the few at the expense of the many. ${ }^{59}$ In addition, the logic of accountability presumes that governments make choices in anticipation of the citizens' preferences for the payoffs that such policies may provide. Our results are consistent with the view that, despite the growth implications of World Bank policies, African governments believed that citizens prefer outcomes generated by policies that violate the tenets of the Washington consensus. ${ }^{60}$ Our findings thus suggest that while the 1980s and 1990s were periods of major political and economic reforms - as the latter is understood by the World Bank - these reforms were not mutually re-enforcing.

\section{APPENDIX: FORMAL RESULTS}

\section{The Model}

Consider an economy with $N$ individuals, indexed by $j \in\{1,2, \ldots, N\}$ in which production is governed by an agent - the government - that manages the transformation between public goods - denoted by $g$ - and private goods - denoted by $f$, subject to the constraint that:

$$
f+\theta g=1, f, g, \theta \geq 0, \theta \leq[(\mathrm{N}-1) / 2]^{2} .
$$

The lower is $\theta$ the more $g$ can be produced for any $f$ forgone; or conversely the more public goods must be forgone to extract private benefits. Private goods may be distributed costlessly to private citizens - the principals - and to the government itself, with $f^{j}$ denoting the allocation to each, subject to $f=\Sigma_{j} f^{j}$. The rents retained by the agent are written $r \equiv f^{l}$. The agent's output then is described by the $(N+1)$-dimensional vector $\left(g,\left\{f^{j}\right\}\right)$. Per-period welfare of the government is given simply by $r$. The per-period welfare of each citizen is given by the quasilinear function: ${ }^{61}$

57 In effect, our models test the joint hypothesis of the logic of accountability and the popularity of particular policy options. Finer measures are needed to separate these hypotheses.

58 Afrobarometer, 'Popular Attitudes to Markets, Selected African Countries, 1999-2000', Afrobarometer Homepage: http://www.afrobarometer.org/survey2.html consulted 10 October 2002.

59 In particular, the studies found that, perhaps because they value the services provided by government or the income from government jobs, Africans do not support policies that cut the size of the public sector. The stylized reporting of the results from the Afrobarometer findings reflect the opinions of majorities in all twelve countries with the sole exception of Tanzania where respondents were more supportive of structural adjustment and, in particular, of the contraction of the public sector.

${ }^{60}$ And evidence reported by Block and Block, Singh et al. underscore the importance of electoral cycles in Africa's economies. See S. A. Block, Political Business Cycles, Democratization, and Economic Performance: The Case of Africa (Medford, Mass.: Tufts University, 1999) and S. A. Block et al., 'Multiparty Competition, Founding Elections, and Political Business Cycles in Africa', CID Working Papers, 80 (2001), http:// www.cid.harvard.edu/cidwip/080.htm.

${ }^{61}$ The argument is readily extended to more general functional forms. 


$$
w^{j}=\sqrt{ } g+f^{j}, j=2,3, \ldots, N .
$$

The utilitarian social welfare function, given by $(N-1) \vee g+\Sigma f^{j}$ is increasing in the creation of public goods and so at the optimum yields (subject to the constraints in (1)), $f=0, g=1 / \theta, w^{I}=0$. In contrast, the optimal set of policies, from the government's perspective, is given by $g=0, f=1, f^{j}=0$ for $j>1$, and $r=f^{1}=1$, yielding $w^{l}=1$.

Assume that all citizens are equal in their powers and that the support of any $M$ citizens is sufficient to maintain the agent in office. With some abuse of notation, we also let $M$ denote an arbitrary coalition of size $M$.

The game between the citizens and their government is played over an infinite number of periods of fixed length; a player's valuation of utility is given by the sum of welfare in each period, discounted for time at constant common rate $\delta \in(0,1)$. In each period we distinguish three phases of play. In the first, each citizen unilaterally selects a minimum satisfaction level, $\omega^{j}$. In the second, the government selects policy. In the third, principals choose non-cooperatively whether to take some costless action to return the government to office. If $M$ citizens choose to return the government to office, they succeed in doing so. If no $M$ citizens support the government, it remains in power nonetheless with probability $q \in(0,1)$. Otherwise, with probability $1-q$, the government is dismissed and a new one is installed. In either case, play returns to the first phase in which principals can again choose performance criteria for the new term of office.

\section{Equilibrium}

We look for equilibria in which citizens employ retrospective voting rules with per-period welfare cutoff points $\left\{\omega^{j}\right\}$ and the government undertakes actions that are feasible; that meet the demands of some set of $M$ principals; and that leave no incentive for any principal to alter her strategies. In what follows we demonstrate that such an equilibrium obtains in which all principals' cut-off points are satisfied by the production of public goods, the government alone consumes private goods, and the equilibrium level of public goods is (weakly) increasing in $\delta$ and $M$, and decreasing in $q$ and $\theta$.

\section{Definition and Benchmarks}

To characterize equilibrium in this game, we use the following definition and benchmarks:

Definition: Principal's Reselection Decision Rule. Let $D_{i}\left(g,\left\{f_{i}\right\}, \omega_{i}\right) \in\{0,1\}$ denote respectively the decisions by individual $i$ to act against or in support of the reselection of the incumbent, conditional upon the output of the principal and the prior demands of the agent.

Note that two benchmark values for $g$ are given as follows.

The Participation Constraint Benchmark [PC]. Should the government act opportunistically it can choose its ideal output, yielding $r=1$. If, in consequence, it fails to attain the support of $M$ principals, then, with probability $(1-q)$, it will consume an out-of-office payoff of 0 for all future periods. To avoid such opportunistic behaviour, an agent's returns from satisfying the demands of principals should provide an outcome at least as beneficial as she may expect from this optimizing behaviour. Letting $g_{P C}$ denote the upper bound on the level of $g$ that a strategic government will be willing to produce while seeking to remain in office, and assuming stationarity, we then have: ${ }^{62}$

$$
g_{P C}=\frac{\delta}{\theta} \frac{1-q}{1-\delta q} .
$$

${ }^{62}$ This is found by equating the payoff for acting opportunistically, $V_{t}^{o p p} \equiv 1+q \delta V_{t+1}$, with the payoff for producing $g_{\mathrm{PC}}$ and subsequently being reappointed: $V_{t}^{\text {coop }} \equiv 1-\theta g_{\mathrm{PC}}+\delta V_{t+1}$. Assuming stationarity, then with $V_{t}^{\text {coop }}=V_{t}^{\text {opp }}$, we have $V_{t}^{\text {coop }}=V_{t+1}$ and can solve for $g_{\mathrm{PC}}$. 
Feasibility Constraint Benchmark [FC]. A second benchmark is the value of $g$ below which citizens are so dissatisfied with the level of public goods provision that the government cannot feasibly purchase the support of $M$ citizens for reduced public goods provision. This value is given by: ${ }^{63}$

$$
g_{F C}=\left(\frac{M}{2 \theta}\right)^{2} \text {. }
$$

When $g>g_{F C}$, then the government can find $M$ players that will be willing to accept a reduction in $g$ in exchange for some feasible increase in $f$. When $g \leq g_{F C}$ it is technically infeasible for the government to reduce $g$ and compensate $M$ players for the loss.

Equilibrium. We now prove the following result:

Claim: The strategy profile $\left\langle\left\{\omega_{i}^{*}\right\}_{i \in\{2,3, \ldots, N\}},\left(g^{*},\left\{f_{i}^{*}\right\}_{i \in N}\right),\left\{D_{i}^{*}\right\}_{i \in\{2,3, \ldots, N\}}\right\rangle$ characterizes a sub-game perfect equilibrium if in every period:

1. $\omega_{j}^{*}=\min \left(g_{\mathrm{FC}}, g_{P C}\right)$ for all $j>1$.

2. $\left(g^{*},\left\{f_{j}^{*}\right\}_{j \in N}\right)$ maximizes $f^{1}$ subject to the constraints that for some set $M, g^{*}+f^{i *} \geq \omega_{i}^{*}$ for all $i$ in $M, f^{*}+\theta g^{*} \leq 1$ and $g^{*} \leq g_{P C}$; if no maximum exists satisfying these constraints, then $f^{*}=1, g^{*}=0$. 3. $D_{j}=1$ if and only if $w_{i} \geq \omega_{i}$.

On the equilibrium path: $\omega_{j}^{*}=g^{*}=\min \left(g_{\mathrm{FC}}, g_{P C}\right)$ for all $j>1, f^{1 *}=f^{*}=1-\theta g^{*}$, and $f^{j *}=0$ and $D_{j}=1$ for $j>1$.

Proof. To prove the result we employ the one-stage deviation principle: we demonstrate that given the strategies of the other players, no deviation for any single period can improve any player's payoff. ${ }^{64}$

Consider first the case where $g_{\mathrm{FC}} \leq g_{P C}$. In this case we claim that on the equilibrium path $g^{*}=g_{\mathrm{FC}}=\omega_{j}^{*}$ for all $j>1$. We wish to demonstrate that (a) the participation constraint of the policy maker is satisfied, (b) the output choice $\left(g_{\mathrm{FC}},\left\{1-\theta g_{\mathrm{FC}}, 0\right\}\right)$ is optimal for the agent, (c) the principals have no incentive to alter their demands and (d) the principals have an incentive to follow the retrospective selection rule. Note first that since $g^{*}=g_{\mathrm{FC}} \leq g_{P C}$ the participation constraint is satisfied. Note next that to maximize $f^{l}$ subject to $f+\theta g \leq 1$, since $g^{*} \leq g_{P C}$, the policy choice that provides $M$ players with utility $\omega_{i}=g_{\mathrm{FC}}$ and that maximizes the agent's utility involves producing $g_{\mathrm{FC}}$ and allocating all of the private goods to the agent. Hence, the principals' demands are met purely by the public good. To check that this is optimal for the agent, note that if $g$ is greater than (or less than) $g_{\mathrm{FC}}$, the agent can increase her income, while satisfying principals, by reducing (or increasing) $g$. Next, since all utility gained by principals derives from consumption of public goods, there are no gains attached to being an element of $M$ and hence no reduction in demands will improve the welfare of any principal; any increase in demands by principal $i$ will be without effect as the agent will exclude principal $i$ from the set she satisfies. Since each principal's decision to support the incumbent is costless, there is in this game no incentive to deviate from the retrospective rule strategy. Consider next the case where $g_{P C} \leq g_{\mathrm{FC}}$. Again, since the agent produces $g_{\mathrm{PC}}$ and consumes all of $f$, her participation constraint is met. Since $g_{P C} \leq g_{\mathrm{FC}}$, the cheapest way to produce $\omega_{i}=g_{P C}$ for $M$ players is to produce the output ( $g_{\mathrm{PC}},\left\{1-\theta_{P C}, 0\right\}$ ), since, if $g<g_{\mathrm{FC}}$ the agent has an incentive to increase $g$ while compensating principals in $M$ to the point where their demands are met. Again, since all utility gained by principals derives from consumption of public goods, no reduction in demands will improve the welfare of any principal and no increase in demands will be satisfied. Again, since each principal's decision to support the incumbent is costless, there is in this game no incentive to deviate from the retrospective rule strategy.

Comparative statics. From inspection of (2) we note that $g_{P C}$ is increasing in $\delta$, and decreasing in $q$ and $\theta$. By inspection of (3) we have that $g_{F C}$ is increasing in $M$ and decreasing in $\theta$. From Claim 1 we have then that $g^{*}$ is (weakly) increasing in $\delta$ and $M$, and decreasing in $q$ and $\theta$.

${ }^{63}$ This is found by solving for the value of $g$ for which: $M\left(\partial w^{\mathrm{j}} / \partial g\right)+\partial f / \partial g=0$ or $(M / 2 \sqrt{ } g)-\theta=0$.

${ }^{64}$ See, for example, D. Fudenberg and J. Tirole, Game Theory (Cambridge, Mass.: MIT Press, 1995), pp. 108-10. 
Reproduced with permission of the copyright owner. Further reproduction prohibited without permission. 